\title{
Noncrystalline Binder Based Composite Propellant
}

\author{
Mohamed Abdullah, F. Gholamian, and A. R. Zarei \\ Faculty of Chemistry, Malek Ashtar University, P.O. BOX 16705-3454, Tehran, Iran \\ Correspondence should be addressed to Mohamed Abdullah; mohamedazizam@gmail.com
}

Received 29 June 2013; Accepted 7 August 2013

Academic Editors: C. Meola and R. K. Sharma

Copyright (C) 2013 Mohamed Abdullah et al. This is an open access article distributed under the Creative Commons Attribution License, which permits unrestricted use, distribution, and reproduction in any medium, provided the original work is properly cited.

\begin{abstract}
This study reports on propellants based on cross-linked HTPE binder plasticized with butyl nitroxyethylnitramine (BuNENA) as energetic material and HP 4000D as noncrystalline prepolymer. This binder was conducted with solid loading in the $85 \%$. The results showed an improvement in processability, mechanical properties and burning rate. In addition, its propellant delivers (about 6 seconds) higher performance (specific impulse) than the best existing composite solid rocket propellant. Thermal analyses have performed by (DSC, TGA). The thermal curves have showed a low glass transition temperature $\left(T_{g}\right)$ of propellant samples, and there was no sign of binder polymer crystallization at low temperatures $\left(-50^{\circ} \mathrm{C}\right)$. Due to its high molecular weight and unsymmetrical or random molecule distributions, the polyether (HP 4000D) has been enhanced the mechanical properties of propellants binder polymer over a large range of temperatures $\left[-50,50^{\circ} \mathrm{C}\right]$. The propellants described in this paper have presented high volumetric specific impulse $\left(>500 \mathrm{~s} \cdot \mathrm{gr} \cdot \mathrm{cc}^{-1}\right)$. These factors combined make BuNENA based composite propellant a potentially attractive alternative for a number of missions demanding composite solid propellants.
\end{abstract}

\section{Introduction}

Much research on composite solid propellants has been performed over the past few decades and much progress has been made, yet many of the fundamental processes are still unknown, and the development of new propellants remains highly empirical. Ways to enhance the performance of solid propellants for rocket and other applications continue to be explored experimentally, including the effects of various additives and the impact of fuel and oxidizer particle sizes on burning behavior.

In view of higher energy $\left(I_{\mathrm{sp}}>264 \mathrm{~s}\right)$, composite propellants have been extensively used for rocket/missile applications and space missions. A higher specific impulse $\left(I_{\mathrm{sp}}\right)$ of composite propellants is obtained by incorporating a maximum possible amount of solids (oxidizer/metallic fuel) in the binder matrix and substituting the inert materials with energetic ones (energetic plasticizers). Present day applications demand propellants of superior mechanical properties in addition to higher energy content. Due to these contradictory requirements hydroxy-terminated polyether (HTPE) based propellants are plasticized with energetic plasticizers, such as BuNENA, bolster performance and mechanical properties [1].

HTPE with HP 4000D as Prepolymer is capable of taking up solids up to $85 \%$ and impart superior mechanical properties without compromising on high storage life, due to its random molecule distributions that prevent crystallization at low temperatures in addition, the presence of BuNENA $\left(T_{g}\right.$ $=-86^{\circ} \mathrm{C}$ ) [2] eliminates completely this phenomenon (crystallization of polyether) at operational temperature ranges $\left[-50,50^{\circ} \mathrm{C}\right]$ of solid rocket motors. Lately, much scholarly work has been done on the hydroxy-terminated polyetherbased (HTPE) propellants instead of hydroxy-terminated polybutadiene-based (HTPB) propellants and has introduced BuNENA as energetic plasticizer in high-energy nitroester polyether (or polyester) (NEPE) propellants [3]. Plasticizer plays the essential role of complementary element to reduce the viscosity of the slurry and to improve the mechanical properties by lowering the $T_{g}$ and the modulus of the binder. The use of BuNENA in composite propellants confers excellent properties, due to its characteristics such as, insensitive energetic material, low glass transition temperatures, and good thermal stability, so we are interested to use it in 
TABLE 1: Materials used in composite propellant binder.

\begin{tabular}{|c|c|c|c|c|c|}
\hline Reagent & Name & Company & Characteristics & $\begin{array}{l}\text { Hydroxyl no. } \\
\text { mg KOH/gm }\end{array}$ & $\begin{array}{c}\text { Molecular } \\
\text { weight } \mathrm{g} / \mathrm{mol}\end{array}$ \\
\hline Prepolymer & HP 4000D & BASF & $\begin{array}{l}\text { Water white } \\
\text { liquid }\end{array}$ & $28-30$ & 4000 \\
\hline Curing agent & N-100 & Bayer & Polyisocyanate & - & 191 \\
\hline Stabilizer & $\begin{array}{l}\text { Nitro diphenyl } \\
\text { amine (2-NDPA) }\end{array}$ & Fluka & Orange crystal & - & 214.22 \\
\hline $\begin{array}{l}\text { Energetic } \\
\text { plasticizer }\end{array}$ & $\begin{array}{l}\text { n-Butyl-2-nitratoethyl-nitramine } \\
\text { (BuNENA) }\end{array}$ & $\begin{array}{l}\text { DYNO ASA, } \\
\text { Norway }\end{array}$ & $\begin{array}{l}\text { Slightly yellow } \\
\text { liquid }\end{array}$ & - & 207.18 \\
\hline Bonding agent & $\begin{array}{l}\text { DYNAMAR Brand Curative } \\
\text { (HX-878) }\end{array}$ & $3 \mathrm{M}$ & $\begin{array}{l}\text { Viscous amber } \\
\text { liquid }\end{array}$ & - & 316.44 \\
\hline
\end{tabular}

TABLE 2: Composite propellant compositions.

\begin{tabular}{lcc}
\hline \multirow{2}{*}{ Ingredients } & \multicolumn{2}{c}{ Percentage by weight } \\
& Mix1 & Mix2 \\
\hline $\mathrm{Al}(22 \mu \mathrm{m})$ & 23.0 & 19.0 \\
$\operatorname{RDX}(5 \mu \mathrm{m})$ & 10.0 & 33.0 \\
$\mathrm{AP}(200 \mu \mathrm{m})$ & 36.4 & 23.1 \\
$\mathrm{AP}(20 \mu \mathrm{m})$ & 15.6 & 9.90 \\
HP4000D & 5.69 & 5.75 \\
BuNENA & 8.00 & 8.00 \\
HX 878 & 0.20 & 0.20 \\
2-NDPA & 0.25 & 0.25 \\
N100 & 0.86 & 0.80 \\
\hline
\end{tabular}

our formulae to improve composite propellant compositions.

A number of studies have been carried out in the past on the formulation, processing, and improvement of mechanical properties and ballistic evaluation of HTPE based composite propellants, but with inert plasticizers and using conventional polyether that can be crystallized at low temperatures [3]. Other studies on double base and gun propellants have been published using BuNENA as energetic plasticizer [4-7]. However, detailed information on composite propellants with energetic plasticizers and new polyether like (HP-4000D) is not reported in the open literature. However, propellants based on cross-linked HTPE binders are being used as alternatives to HTPB compositions because they give a less severe response in slow cookoff tests for insensitive munitions (IM) compliance [8-10].

\section{Experimental}

2.1. Materials. Bimodal blends of AP were used, consisting of a medium sized $(200 \mu \mathrm{m})$ fraction and a small sized $(20 \mu \mathrm{m})$ fraction. This combination was recommended as offering an optimum AP particle size width distribution to give the best rheology and to improve propellant slurry processabillity, and also, RDX 5 microns and $\mathrm{Al}$ of 23 micron were used as filler in the propellant composition. Materials used for binder have been described in Table 1.
2.2. Propellant Processing and Characterization. The propellant ingredients were mixed in a 3-liter capacity sigma mixer for two batches (mixl, mix2) prepared according to Table 2. The processability of the slurry was monitored by measuring the end-of-mix viscosity (EOM) and viscosity build up for a period of 10 hours. Propellant slurry was cast into Teflon coated moulds, under vacuum, for evaluation the mechanical properties and strand burn rate. The mechanical properties of cured propellant samples were evaluated using dumb bells conforming to ASTM standards D-412-68 (Type-C) at a cross-head speed of $50 \mathrm{~mm} / \mathrm{minute}$ at $-40,25$, and $50^{\circ} \mathrm{C}$. The cured propellant slabs were machined into strands of dimensions $175 \times 5 \times 5 \mathrm{~mm}$. The strands were inhibited with coatings of phenolic epoxy resin or polyvinyl acetate paint. They were burned in a nitrogen pressurized Crawford-type bomb over a pressure range from 2 to $18 \mathrm{MPa}$.

\section{Results and Discussion}

3.1. Mechanical and Ballistic Properties. As seen in Table 3, propellant samples, mix1 and mix2, exhibit a high density impulse $\left(\sim 500 \mathrm{~g} \cdot \mathrm{s} \cdot \mathrm{cc}^{-1}\right)$, good processabillity expressed by low viscosity of EOM ( $\sim 4 \mathrm{~K}$ Poise), and reasonable pot life (8 hours). In addition, it has shown excellent mechanical properties especially at low temperatures $\left(-40^{\circ} \mathrm{C}\right)$ when binder elongation at maximum stress reached to $65-70 \%$. Thus, we have believed that the withstanding properties refer to kind of prepolymer used and to the presence of BuNENA in composition. The use of HP 4000D, as prepolymer, which is Ethylene-Oxide (EO) capped polypropylene glycol (PPG) polyols with low insaturation content, also when plasticized with BuNENA, which has low glass transition temperature $\left(T_{g}=-86^{\circ} \mathrm{C}\right)$, has enhanced the binder elongation at low temperatures and prevented binder to crystallize (improved by thermal behavior next). When more RDX is used (mix2), the burning rate and pressure exponent decreased, respectively; see Table 3 . In addition, mix 2 showed increase in specific impulse (about 4 seconds).

3.2. DSC and TGA Analyses. In order to analyze the thermal behavior of propellant samples, differential scanning calorimeter (DSC) analysis was performed to determine glass transition temperature $\left(T_{g}\right)$ and thermal decomposition (TA). Thermogravimetric analyses (TGA) were also carried 
TABLE 3: Mechanical, rheological, and ballistic properties of propellant samples.

\begin{tabular}{|c|c|c|c|c|c|c|c|}
\hline Composite propellants & Unit & \multicolumn{3}{|c|}{ Mixl } & \multicolumn{3}{|c|}{ Mix2 } \\
\hline Density, $\rho$ & $\mathrm{g} \mathrm{cm}^{-3}$ & \multicolumn{3}{|c|}{1.88} & \multicolumn{3}{|c|}{1.83} \\
\hline Specific impulse (theoretical), 7/0.1 MPa & $\mathrm{sec}$ & \multicolumn{3}{|c|}{266} & \multicolumn{3}{|c|}{270} \\
\hline Density specific impulse $\left(\rho \cdot I_{\mathrm{sp}}\right)$ & $\mathrm{g} \cdot \mathrm{cm}^{-3} \mathrm{sec}$ & \multicolumn{3}{|c|}{500} & \multicolumn{3}{|c|}{494} \\
\hline Burning rate at $7 \mathrm{MPa}$ & $\mathrm{mm} \mathrm{s}^{-1}$ & \multicolumn{3}{|c|}{8.50} & \multicolumn{3}{|c|}{7.00} \\
\hline Pressure exponent $(n),(2-18) \mathrm{MPa}$ & - & \multicolumn{3}{|c|}{0.45} & \multicolumn{3}{|c|}{0.40} \\
\hline \multicolumn{8}{|l|}{ Processability } \\
\hline End of mixing (EOM) viscosity & K Poise & & 4.0 & & & 4.5 & \\
\hline Pot life (to $15 \mathrm{~K}$ poise) & hour & & 8 & & & 10 & \\
\hline Mechanical Properties $T^{\circ} \mathrm{C} / / 50 \mathrm{~mm} \mathrm{~min}^{-1}$ & $T^{\circ} \mathrm{C}$ & -40 & 25 & 50 & -40 & 25 & 50 \\
\hline Max. tensile strength $\sigma_{\max }$ & $\mathrm{N} \mathrm{mm}^{-2}$ & 1.5 & 0.8 & 0.6 & 1.8 & 0.7 & 0.5 \\
\hline Elongation at $\varepsilon_{\max }$ & $\%$ & 65 & 78 & 86 & 58 & 70 & 78 \\
\hline Elongation at break & $\%$ & 70 & 86 & 91 & 63 & 76 & 81 \\
\hline E-modulus & $\mathrm{N} \mathrm{mm}^{-2}$ & 5.5 & 2.2 & 1.8 & 5.8 & 2.0 & 1.6 \\
\hline Glass transition DSC & ${ }^{\circ} \mathrm{C}$ & & -75.03 & & & -77.47 & \\
\hline
\end{tabular}

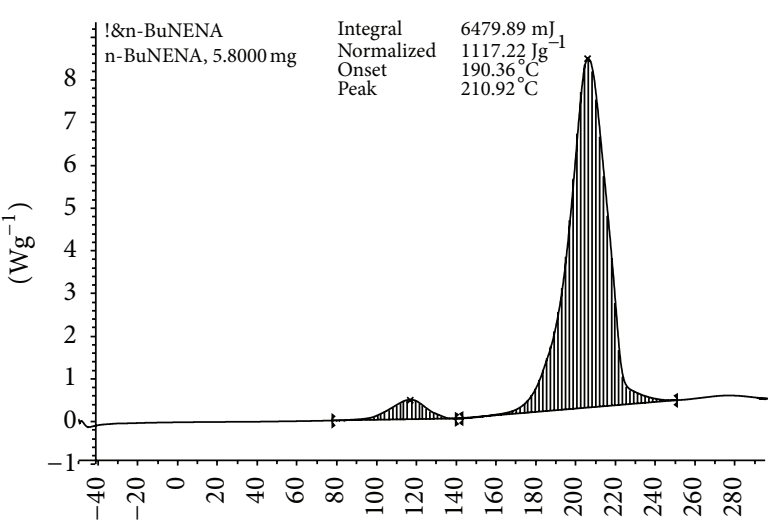

$\left({ }^{\circ} \mathrm{C}\right)$

Figure 1: BuNENA DSC curve.

out. The thermal analyses were performed using Mettler TA4000 thermal analyzer equipped with a TA processor TC11 and a DSC 30 measuring cell. An inert environment was maintained during all the analyses by using a flow of nitrogen of $40 \mathrm{~cm}^{3}$ per min. Analyses were performed at a heating rate of $10^{\circ} \mathrm{C}$ per min in the temperature range from -100 to $+30^{\circ} \mathrm{C}$ for $\mathrm{T}_{g}, 30$ to $500^{\circ} \mathrm{C}$ for TA analysis, and 30 to $550^{\circ} \mathrm{C}$ for TGA. Figure 2 shows the DSC $T_{g}$ curve of propellant sample mixl (9.8 $\mathrm{mg}$ of sample), and Figure 3 is related to sample mix2 (5.4 mg of sample). As we have shown, $T_{g}$ is $75.03^{\circ} \mathrm{C}$ corresponding to mixl and $77.47^{\circ} \mathrm{C}$ to mix 2 . Figure 4 shows the DSC TA curve of ( $0.9 \mathrm{mg}$ of sample) mixl and Figure 5 shows the DSC TA curve $(2.2 \mathrm{mg})$ of sample mix 2 . Figure 6 shows the thermogravimetric curve $(4.3 \mathrm{mg}$ ) of sample mixl.

As can be seen from Figures 2 and 3, the glass transition temperatures for propellant samples mixl and mix 2 are very close. The $T_{g}$ for these samples was around $-76^{\circ} \mathrm{C}$. On the other hand, the thermal decomposition observed in Figures 4 and 5 and several peaks, either exothermic or endothermic, are present during propellant thermal decomposition. Three endothermic peaks can be seen after $150^{\circ} \mathrm{C}$ from samples mixl

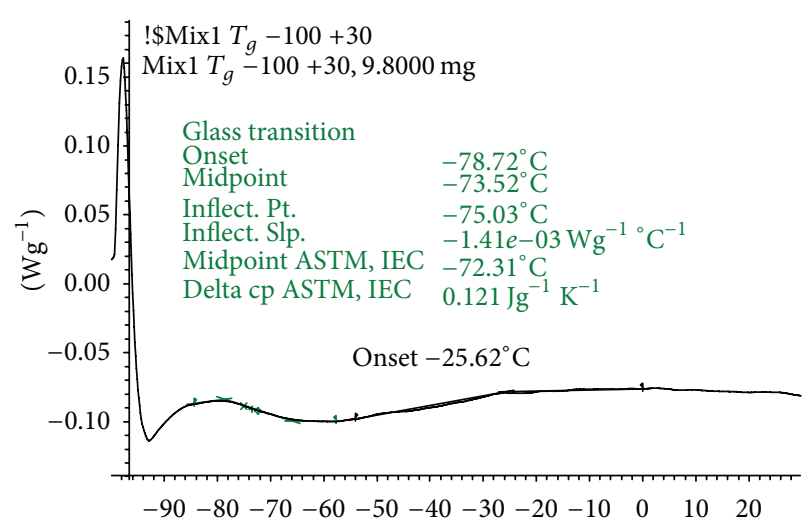

$\left({ }^{\circ} \mathrm{C}\right)$

FIGURE 2: DSC $T_{g}$ curve of propellant sample (mixl).

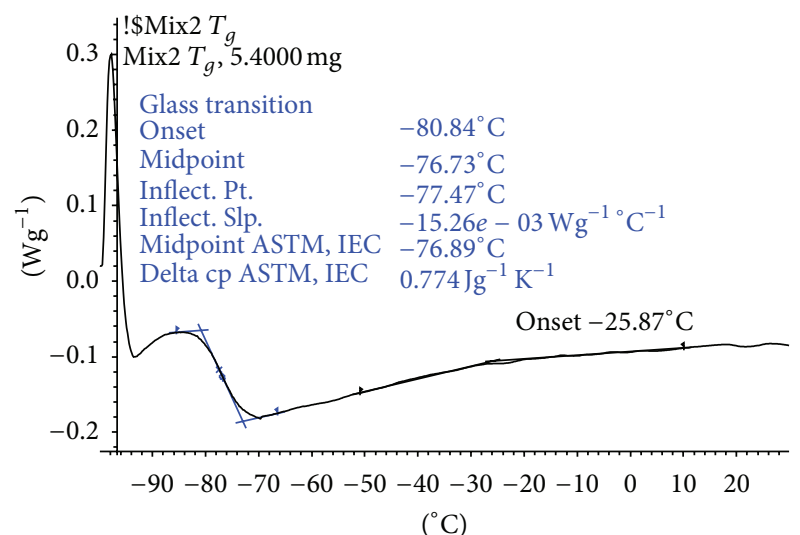

FIGURE 3: DSC $T_{g}$ curve of propellant sample (mix2).

and mix 2 in Figures 4 and 5, respectively. The exothermic peaks at around 188 and $193^{\circ} \mathrm{C}$, with an onset around $160^{\circ} \mathrm{C}$, can be assigned to the energetic plasticizer BuNENA. In propellant mixl, this peak can be seen at $199^{\circ} \mathrm{C}$ and it looks 


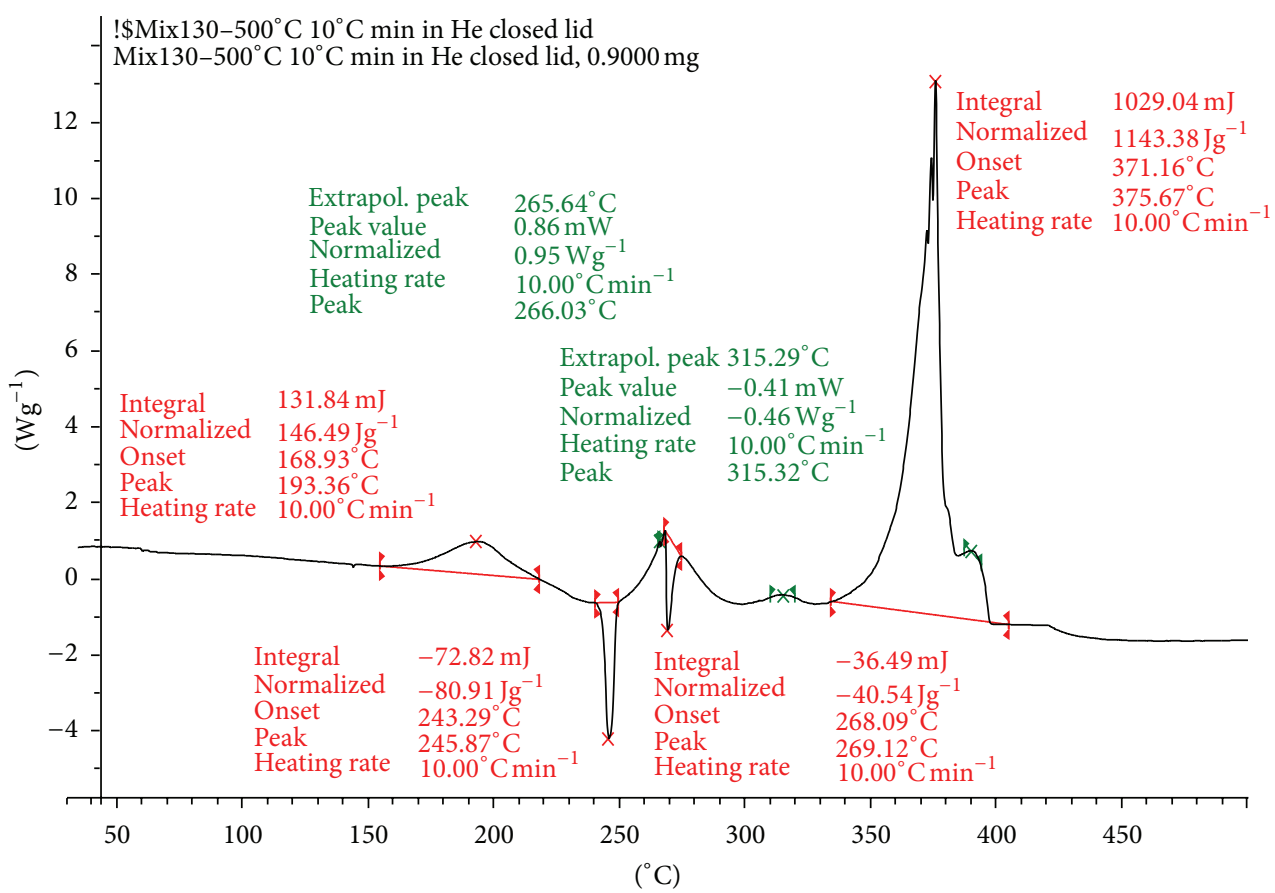

FIGURE 4: DSC TA curve of propellant sample (mixl).

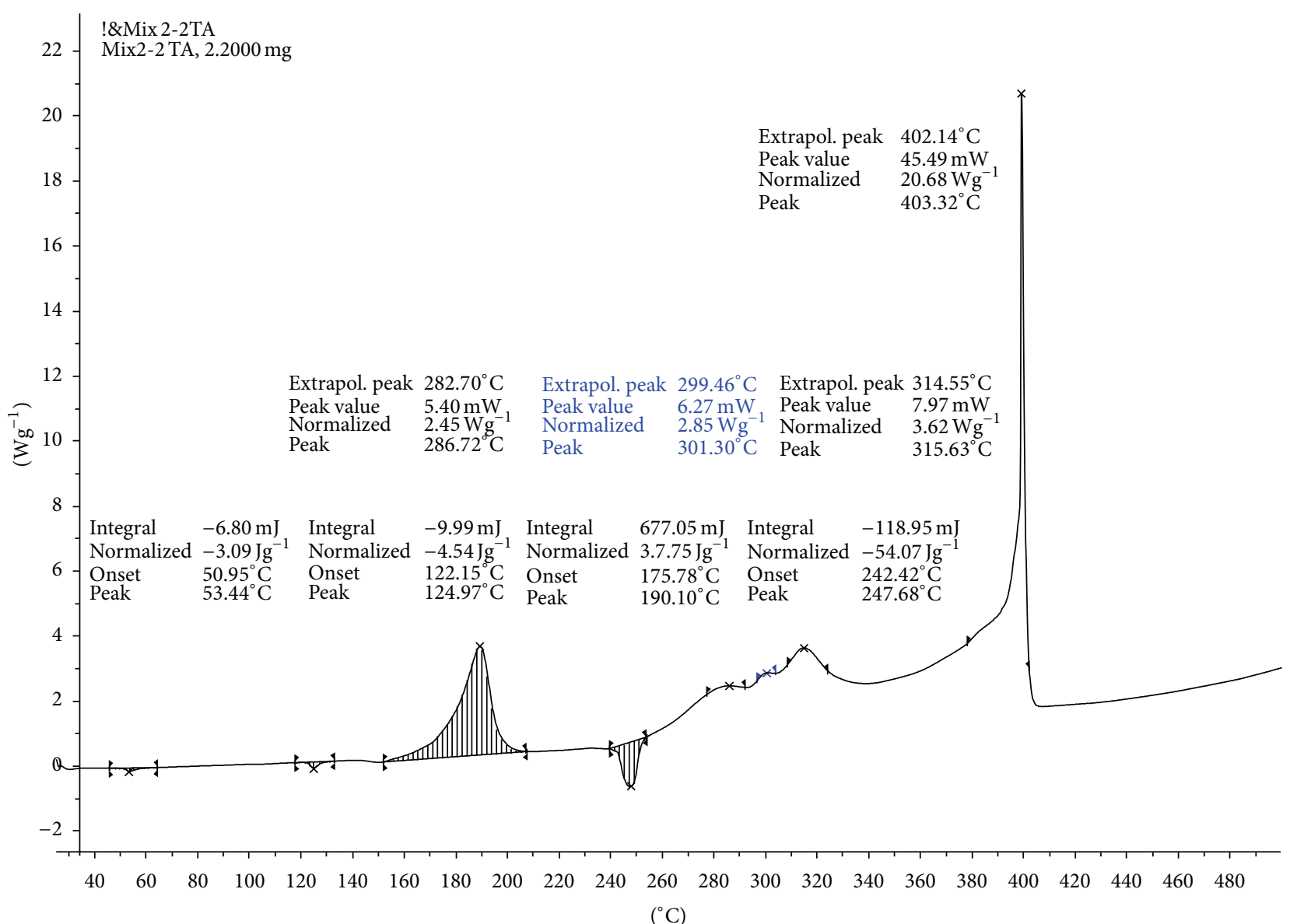

FIgURE 5: DSC TA curve of propellant sample (mix2). 


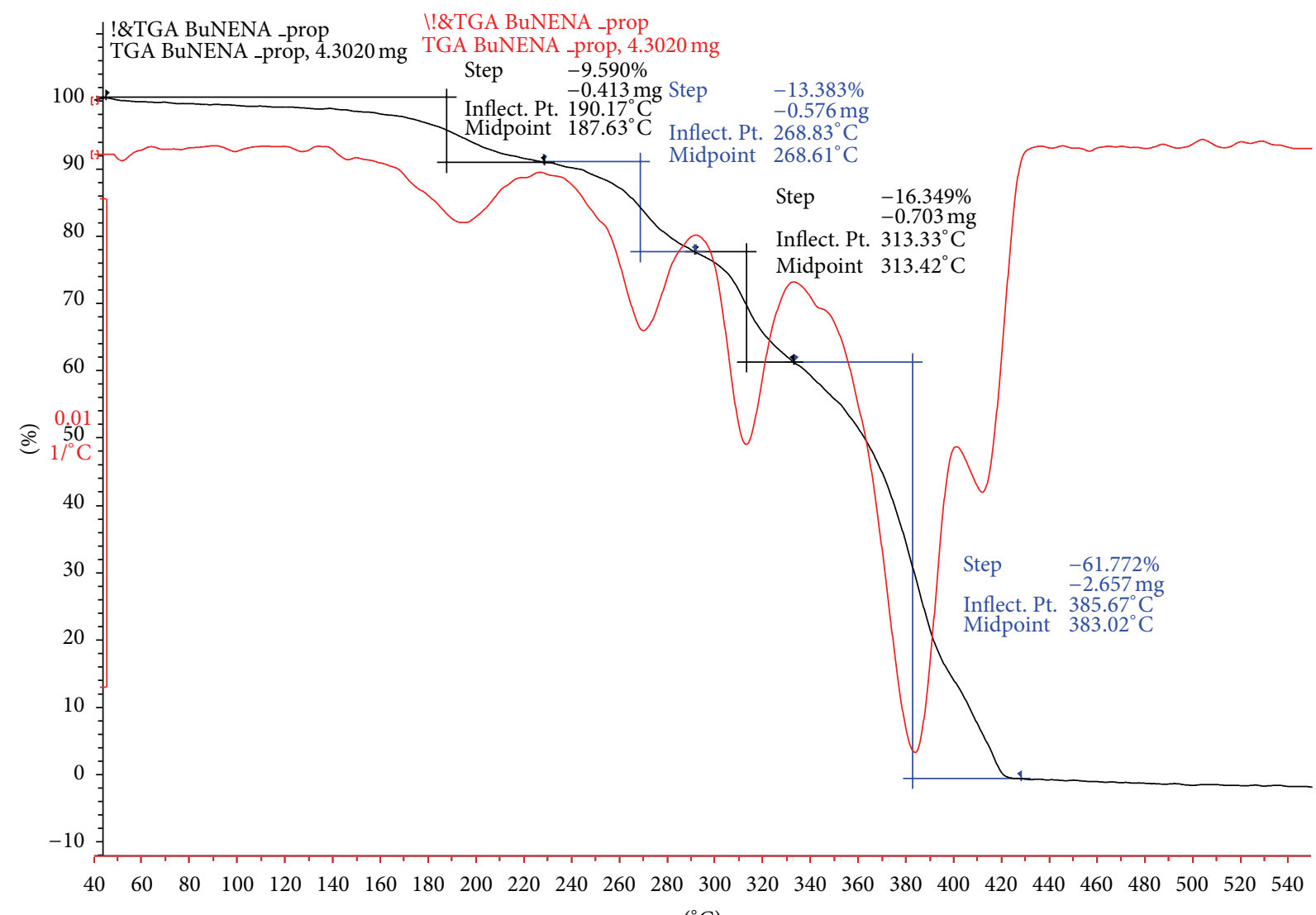

$\left({ }^{\circ} \mathrm{C}\right)$

FIgURE 6: TGA curve of propellant sample (mixl).

more intense than in the other propellant mix2, as can be seen in Figure 5. In fact, in mixl the heat of decomposition was $1143 \mathrm{~J} \mathrm{~g}^{-1}$ and the BuNENA heat of decomposition peak for the pure product was observed to be $1117 \mathrm{Jg}^{-1}$ at $210^{\circ} \mathrm{C}$ (Figure 1). Figure 6 shows the thermo gravimetric for $4.3 \mathrm{mg}$ of sample Bu NENA prop. Several peaks are present during propellant thermal decomposition. The peak at around $190^{\circ} \mathrm{C}$ with weight loss $9.6 \%$ refers to Bu NENA, and around $268^{\circ} \mathrm{C}$ with weight loss $13.88 \%$, refers to RDX. Two peaks at 313.33 , and $385.65^{\circ} \mathrm{C}$ with weight losses 16.4 , and $61.77 \%$ can be assigned to the AP decompositions on two stages.

\section{Conclusions}

Composite solid propellant, based on HP 4000D as prepolymer, BuNENA as energetic plasticizer, and Al/AP/RDX as fillers, clearly demonstrated that the specific impulse $I_{\mathrm{sp}}$ could be increased (about 6 seconds) as compared to the best existing type of composite propellant. The results are very promising, especially to the mechanical properties at low temperatures, as well as to the polymer rheology expressed by processability (good castability, low viscosity, and relatively long pot life). The paper found, however, that the difunctional end-capped propylene prepolymer block, that is made by and commercially available from BASF Corporation under the trade name $\mathrm{HP}-4000 \mathrm{D}$, which is a high performance difunctional prepolymer, having an average molecular weight of 4000 , is the best solution to reduce the tendency of the polyether to crystallize. The low temperature strain values indicate that the energetic composition has excellent elastomeric properties over a broad range of temperatures, as well as very high strain capability and tensile strength. These properties exceed even HTPB propellants in some instances, while providing higher oxygen content than HTPB. In the search for replacement of inert plasticizers for composite propellants, BuNENA is a new and very promising, interesting material with high performance and low vulnerability. On the other hand, RDX has been shown to be a very useful energetic ingredient in solid rocket propellant applications, due to its relative insensitivity to accidental energy stimuli. In addition, the absence of $\mathrm{HCl}$ in $\mathrm{RDX}$ combustion products makes it desirable on an environmental basis. Since the regression rate and burning behavior of a solid propellant can be greatly influenced by processes occurring in the burning surface and subsurface regions, so pressure exponent can be reduced. To improve the specific impulse of cross-linked HTPE propellant plasticized with BuNENA, RDX must be introduced in propellant composition (at least 10\%), and when reaches $33 \%$, the specific impulse increases to $270 \mathrm{~s}$. The presence of RDX in composition formula has an effect on specific impulse and pressure exponent $(n)$. In addition, more than $500 \mathrm{~g} \cdot \mathrm{cm}^{-3} \mathrm{sec}$ of density impulse are expected. 


\section{References}

[1] M. E. Sitzmann, N. J. Trivedi, and B. Patrick, "Investigation of an N-Butyl-N-(2-Nitroxyethyl)nitramine (BuNENA) process: identification of process intermediates, by-products and reaction pathways," Propellants, Explosives, Pyrotechnics, vol. 31, no. 2, pp. 124-130, 2006.

[2] N. Wingborg and C. Eldsäter, "2,2-Dinitro-1,3-bis-nitrooxypropane (NPN): a new energetic plasticizer," Propellants, Explosives, Pyrotechnics, vol. 27, no. 6, pp. 314-319, 2002.

[3] B. S. Min and Y. C. Park, "A study on the aliphatic energetic plasticizers containing nitrate ester and nitramine," Journal of Industrial and Engineering Chemistry, vol. 15, no. 4, pp. 595-601, 2009.

[4] K. P. C. Rao, A. K. Sikder, M. A. Kulkarni, M. M. Bhalerao, and B. R. Gandhe, "Studies on n-Butyl nitroxyethylnitramine (n-BuNENA): synthesis, characterization and propellant evaluations," Propellants, Explosives, Pyrotechnics, vol. 29, no. 2, pp. 93-98, 2004.

[5] P. A. Silver and N. F. Stanley, "BuNENA gun propellants," in Proceedings of the JANNAF Propulsion Meeting, vol. 2, p. 515, Anaheim, Calif, USA, September 1990.

[6] Alu, Q. Shen, X. Liao, and G. Bao, "Preliminary study of BuNENA gun propellant," in Proceedings of the 27th International Annual Conference on ICT, (Energetic Materials), p. 51. 1, Karlsruhe, Germany, 2006.

[7] L. A. Fang, S. Q. Hua, L. Xin, and V. G. Ling, "Preliminary study of $\mathrm{Bu}$ NENA gun propellants," in Proceedings of the 27th International Annual Conference of ICT, p. 51/1, Karlsruhe, Germany, June 1996.

[8] NIMIC Newsletter, "Solid rocket propellant for improved IM response, part 2," IM Propellant Examples, vol. 1, pp. 2-4, 2003.

[9] D. Schmitt, P. Eyever, and P. Elsner, "Insensitive high performance energetic materials-applied research for optimized products," Propellants, Explosives, Pyrotechnics, vol. 22, no. 3, pp. 109-111, 1997.

[10] T. F. Comfort, L. G. Dillman, K. O. Hartman, M. G. Mangum, and R. M. Steckman, "Insensitive HTPE propellants," in Proceedings of the JANNAF Propulsion Meeting, vol. 3, p. 87, CPIA Publication 630, Tampa, Fla, USA, December 1995. 

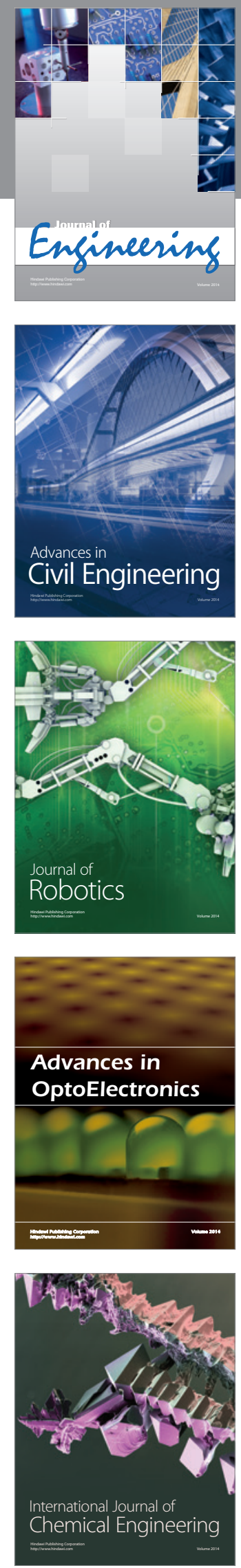

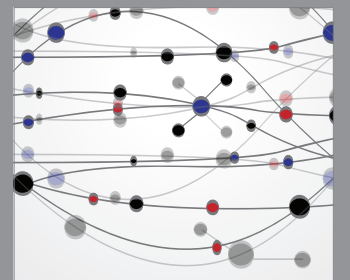

The Scientific World Journal
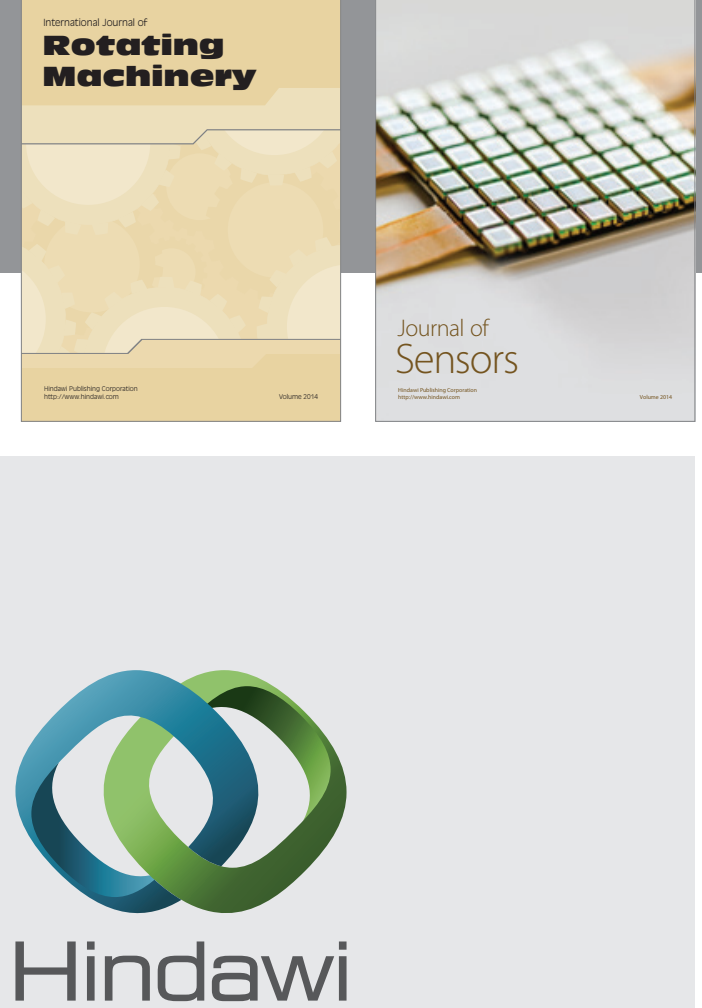

Submit your manuscripts at http://www.hindawi.com
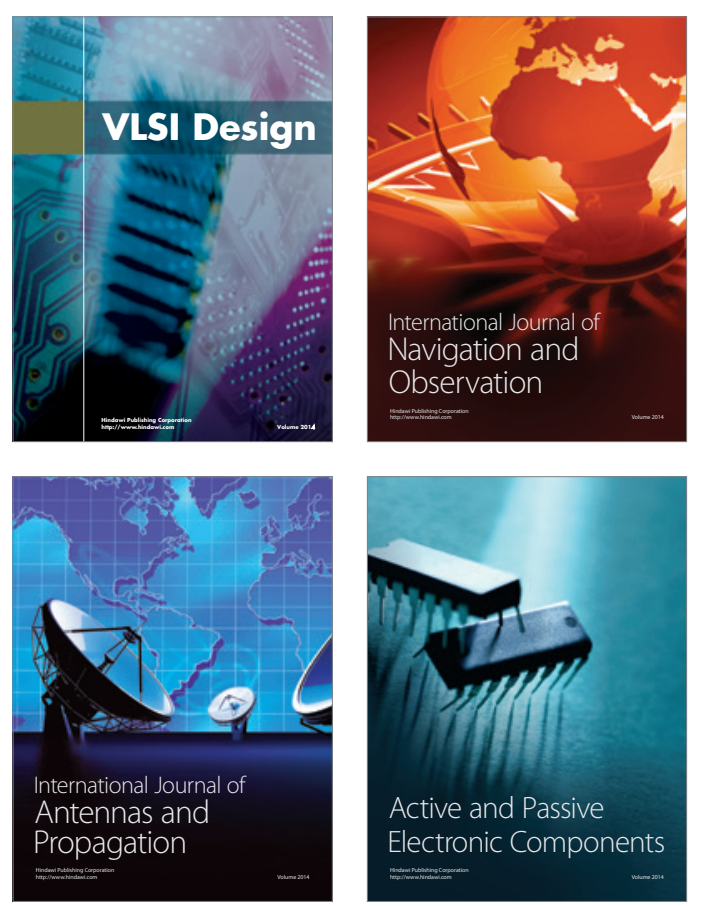
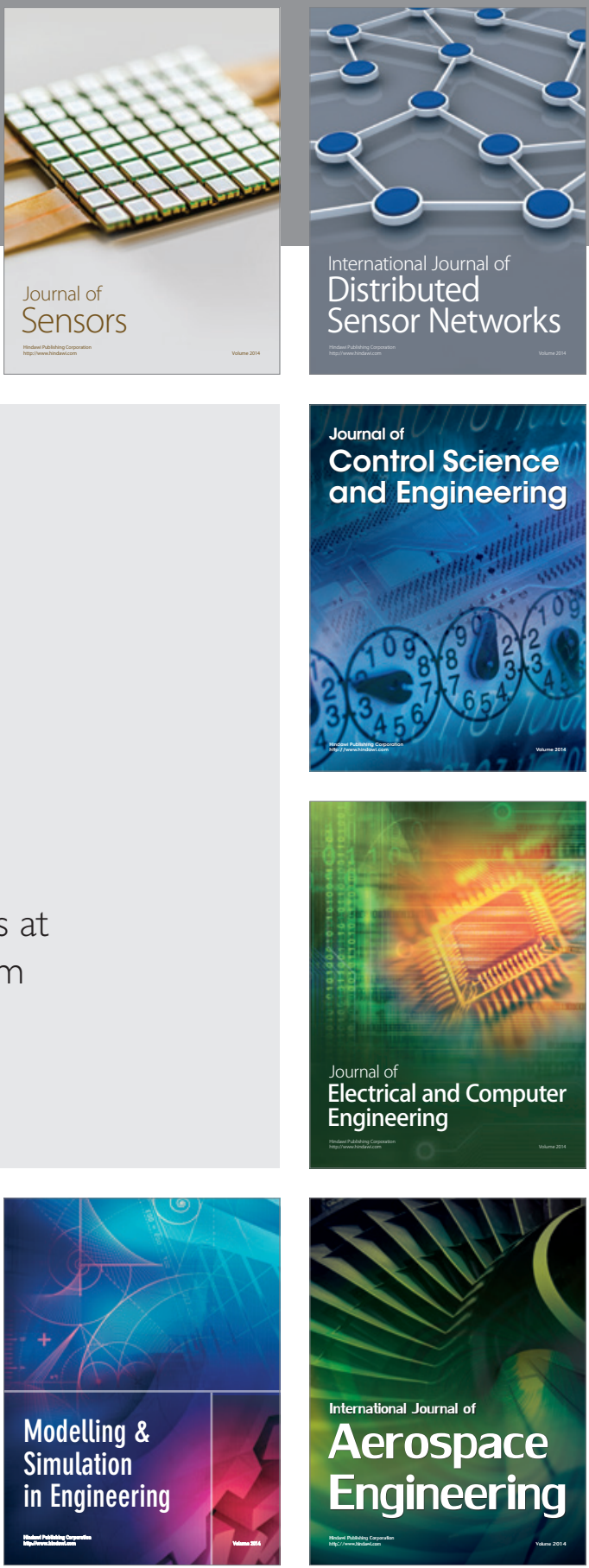

Journal of

Control Science

and Engineering
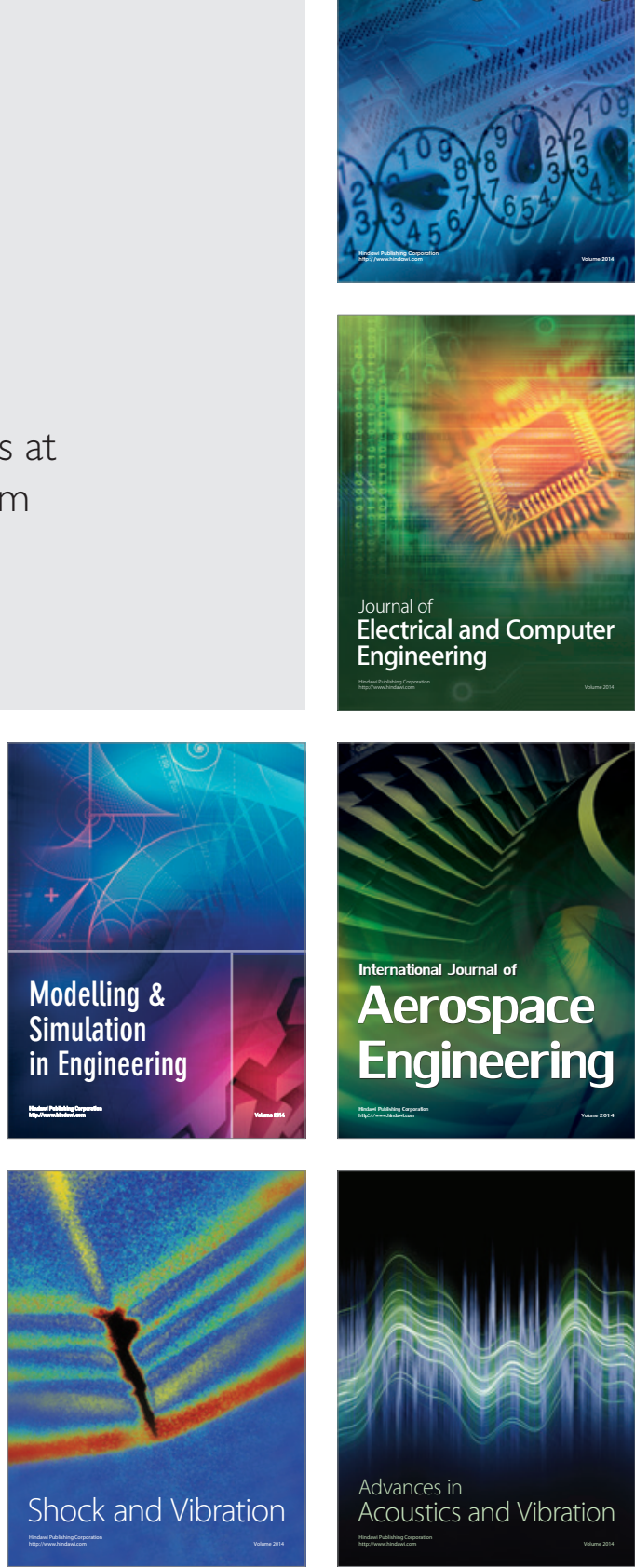